\title{
RAZVOJ KONTEJNERIZACIJE U SVIJETU I ANALIZA KONTEJNERSKOG PROMETA U LUCI RIJEKA
}

\author{
Barbara Rudić \\ Mag. oec., viši predavač, Veleučilište u Rijeci, Vukovarska 58, 51000 Rijeka, Hrvatska; \\ e-mail:barbara.rudic@veleri.hr \\ Erika Gržin \\ Struč. spec. ing. traff., predavač, Veleučilište u Rijeci, Vukovarska 58, 51000 Rijeka, Hrvatska; \\ e-mail:erika.grzin@veleri.hr
}

\begin{abstract}
SAŽETAK
Kontejnerizacija je utjecala na razvoj međunarodne trgovine, te je postala nezamjenjiv oblik prijevoza robe, spajajući pomorski, cestovni i željeznički prijevoz u cjeloviti transportni lanac. Stoga je cilj ovog rada ukazati na važnost kontejnerizacije, prikazati stanje kontejnerskog prometa u svijetu i analizirati kontejnerski promet u Hrvatskoj na primjeru luke Rijeka. Rad sadržava razvoj kontejnerizacije te pokazatelje vezane za promet kontejnera u najvećim svjetskim morskim lukama, kao i pokazatelje najvećih kontejnerskih brodara. U radu je naglašena važnost glavnih elemenata kontejnerizacije te ostali sudionici u sustavu kontejnerizacije. Prikupljeni podaci analizirani su primjenom metoda deskriptivne statističke analize. Rezultati pokazuju konstantni rast svih elemenata kontejnerizacije na svjetskoj razini. Na razini Hrvatske, na primjeru luke Rijeka, također su vidljivi pozitivni rezultati na području kontejnerskog prometa.
\end{abstract}

Ključne riječi: razvoj kontejnerizacije, kontejnerski promet, kontejnerski brod, luka Rijeka, analiza

\section{UVOD}

Kontejnerizacija i kontejnerski promet doživjeli su u posljednjih nekoliko desetljeća veliku transformaciju i razvoj. Uvođenje tehnoloških inovacija i standardizacija dimenzija kontejnera omogućili su učinkovitiji prijevoz različitih vrsta tereta, te je kontejnerizacija postala nezamjenjiv oblik prijevoza robe u međunarodnom pomorskom i kopnenom prometu.

Pregled literature upućuje na različita istraživanja prema kojima kontejnerizacija i promet kontejnera pozitivno utječu na razvoj trgovine, ekonomski rast, razvoj lučke infrastrukture i logističke procese (Heaver, 2002., Bernhofen et al. 2016.). Nadalje, prema Hlali i Hammami (2019.), kontejnerizacija čini $80 \%$ ukupnog prijevoza robe morem, te ima značajnu ulogu u svjetskoj međunarodnoj trgovini. 
U posljednjem je desetljeću u domaćoj literaturi objavljeno nekoliko radova povezanih s konceptom kontejnerizacije. Tako su Kos et al. (2010) analizirali relevantne parametre kontejnerskih morskih luka Rijeka, Split i Ploče. Slično, Zelenika et al. (2011) analizirali su uspješnost poslovanja teretnih morskih luka u Hrvatskoj. Rudić et al. (2013) istraživali su probleme funkcioniranja lučkog sustava i poslovanja kontejnerskog terminala na primjeru luke Rijeka. O značajkama kontejnerskih brodova i njihovom razvoju pisali su Erak et al. (2015), Mišković et al. (2016) i Vladimir et al. (2017).

Cilj ovog rada je ukazati na važnost kontejnerizacije, prikazati stanje kontejnerskog prometa u svijetu i analizirati kontejnerski promet u Hrvatskoj na primjeru luke Rijeka. $U$ tu su svrhu korišteni sekundarni podaci objavljeni u tiskanim publikacijama i na internetu. Analiza prikupljenih podataka temelji se na primjeni metoda deskriptivne statističke analize.

Rad je strukturiran kako slijedi. Nakon uvodnog dijela s kratkim pregledom dosadašnjih istraživanja koncepta kontejnerizacije, slijedi teorijsko opredjeljenje osnovnih pojmova vezanih uz glavnu temu rada. U nastavku rada analiziran je kontejnerski promet u svijetu i u Hrvatskoj na primjeru luke Rijeka. Na kraju su predstavljeni glavni zaključci i prijedlozi za buduća istraživanja.

\section{TEORIJSKO OPREDJELJENJE OSNOVNIH POJMOVA I RAZVOJ KONTEJNERIZACIJE}

\section{1 Razvoj kontejnerizacije}

Naziv kontejner potječe od engleske riječi „,ontainer" (contain-sadržavati) a znači sve ono što u sebi može sadržavati nešto drugo.

„Kontejner je manipulativna prijevozna oprema, najčešće u obliku zatvorene posude, koja služi za formiranje krupnih manipulativnih jedinica tereta u cilju racionalizacije manipulacijskih i skladišnih operacija" (www. prometna-zona.com/kontejneri-i-kontejnerizacija/).

Proizvodnja kontejnera iz godine u godinu ima sve veći uzlazni trend razvoja, kako po broju, tako i po opsegu, ali i po sve većoj suvremenosti. Godišnja proizvodnja iznosi oko 700 tisuća kontejnera raznih dimenzija i namjena. Samo u pomorskom brodarstvu sada u svijetu ima oko 9 milijuna TEU kontejnera.

Sve se više proizvode veći kontejneri (iznad 40 stopa), i to od 45, 48, 53 i 60 stopa.

U početku i polovicom osamdesetih godina proizvodnja kontejnera premještena je sa Zapada na Daleki istok, posebice Republiku Koreju, koja je imala komparativne prednosti u odnosu na ostale zemlje tržišne ekonomije.

Kontejnerizacija pomorskog i kopnenog prometa ne može postojati bez određenog sustava kontejnera. Osim kontejnera za kontejnerizaciju prometa potrebna su prekrcajna sredstva te ostala potrebna oprema za podešavanje i privez kontejnera u toku prijevoza.

Formiranje, funkcioniranje i održavanje potrebnog i stabilnog sustava kontejnera, vrlo su značajna pitanja i temeljne pretpostavke za uspješnu kontejnerizaciju. 
Kapaciteti kontejnerskih brodova , kontejnerski terminali i kontejnerski depoi značajno utječu na optimalno stanje i funkcioniranje sustava kontejnera svakog kontejnerskog brodara.

Kontejnerizacija nekog kontejnerskog servisa, veličina brodova, kao i poteba za vrstom kontejnera na nekoj razini definiraju potrebu za brojem kontejnera i vrstom kontejnera.

Uz ostalo vrlo značajno pitanje predstavlja i struktura sustava kontejnera nekog brodara prema vlasništvu. Tako su nekada u počecima kontejnerizacije prijevoznici u pomorskom i željezničkom prometu imali pretežito vlastite kontejnere, što je zahtijevalo velike investicije u vlastite kontejnere te posebice probleme oko praćenja i prebacivanja te skladištenja praznih vlastitih kontejnera.

U novije vrijeme $u$ svijetu su se formirale posebne velike kompanije koje se bave davanjem kontejnera u zakup na određeno putovanje, nakon čega se prazni kontejneri na odredištu prepuštaju vlasniku kontejnera.

Zbog održavanja stabilnog sustava kontejnera, kontejnerski brodovi imaju službu za praćenje kontejnera. Dobro organizirana služba praćenja kontejnera podrazumjeva sposobne i iskusne kadrove kao i suvremenu opremu koja osigurava dobru povezanost sa brodovima te posebice sa kontejnerskim terminalima u svijetu te povezanost sa poslovnim partnerima po pitanju stanja i kretanja kontejnera.

Sustav kontejnerskog prometa privlači veliku pozornost jer je to jedan od vrlo značajnih oblika suvremenih tehnologija prometa, a nekoliko zadnjih desetljeća kontejnerizacija ima iznimno značanje u prijevozu robe od proizvođača do potrošača.

Sustav kontejnerskog prometa je složeni sustav koji osigurava brz i racionalan prijevoz roba širom svijeta. Velike prednosti kontejnerskog prijevoza temelje se na sustavu kontejnera, normizaciji prijevoznih sredstava, te raznim prekrcajnim sredstvima na kontejnerskim terminalima.

\section{2 Važnost i prednosti kontejnerizacije}

Analizirajući brzi razvoj kontejnerizacije zadnjih desetljeća u svijetu i značenje kontejnerizacije za razvoj svjetske trgovine mnogi stručnjaci i znanstvenici istražuju elemente koji su doprinjetli razvoju i širenju kontejnerizacije. Nakon analize došlo se do zaključka da postoji veliki broj prednosti koje su dovele do tako naglog razvoja kontejnerizacije. Od brojnih prednosti, posebno se u teoriji razvoja kontejnerizacije mogu navesti neke, kao što su:

- brzina prijevoza kontejnera

- sigurnost prijevoza tereta

- integracija svih oblika tereta

- ekonomičnost prijevoza

- primjena suvremenih strategija prometa i logistike

- spoznaje o mogućnosti razvoja kontejnerizacije u budućnosti 
Zahvaljujući osnovnim obilježjimai prednostima kontejnerizacije, došlojedoširenja kontejnerizacije, naročito u pomorskom prijevozu. Počeli su se graditi sve veći i složeniji kontejnerski brodovi. Na taj način stvoreni su brodski kapaciteti koji omogućuju kontejnerski prijevoz raznih vrsta tereta, među kojima i onih tereta koji su u početku kontejnerizacije smatrani nepogodnima za kontejnerski pomorski prijevoz (Rudić, 1997:74).

Kontejnerizacija u pomorskom prometu omogućila je okrupnjavanje tereta ili robe u velike standardne transportne jedinice i omogućila velike učinke u rukovanju s robom što je smanjilo vrijeme boravka linijskih kontejnerskih brodova u lukama, što je dugo vremena bio jedan od glavnih problema linijskog brodarstva.

Analizirajući naglo širenje i afirmaciju kontejnerizacije, treba naglasiti veliki doprinos međunarodnih i nacionalnih organizacija koje definiraju standarde, označavanje i evidenciju kontejnera. Osim navedenog međunarodne organizacije definiraju procese i dokumentaciju u prijevozu kontejnera.

Velika važnost razvoja kontejnerizacije sastoji se i u realizaciji suvremenih ekonomskih i logističkih strategija, kao što su brzina, sigurnost, racionalnost prijevoza, dostava robe od vrata do vrata i druge.

Razvoj kontejnerizacije na globalnoj razini najbolje predstavljaju glavni elementi kontejnerizacije koji se daju i analiziraju u narednim podtočkama ovoga poglavlja.

\subsection{Kontejnerski brodovi}

Od svojih početaka dizajn brodova za prijevoz kontejnera se mijenjao tijekom vremena prateći potrebe tržišta i razvoj tehnologije (Mišković, et al., 2016.). Da bi se ostvarile sve velike prednosti kontejnerizacije na svjetskoj razini, bilo je nužno napraviti preokret u gradnji i konstrukciji kontejnerskih brodova. Analizom razvoja linijskih brodova za generalne terete u pomorskom prijevozu, može se zaključiti da su ti brodovi imali velike probleme na području brzine, sigurnosti i dobrog korištenja kapaciteta. Svi zahvati i poboljšanja tokom vremena nisu davali značajnije rezultate, posebice pokušaji da se linijski brodovi kraće zadržavaju u lukama.

Izgradnja potpuno kontejnerskih brodova velikog kapaciteta i velike brzine kao i osiguranje velikih prekrcajnih mogućnosti na dobro opremljenim pomorskim terminalima doveli su do prave revolucije u pomorskom prijevozu te ukupnom prijevozu robe širom svijeta.

Uvođenje u pomorski promet velikih i skupih kontejnerskih brodova tražilo je izgradnju novih lučkih terminala kao i nabavku novih i skupih prekrcajnih sredstava, kao što su velike dizalice i brojna mehanizacija za rukovanje s kontejnerima na kontejnerskom terminalu.

Upravo zbog novih koncepcija i velikih financijskih ulaganja nije bilo stručnjaka u morskom brodarstvu i morskim lukama koji su mogli zamisliti tako brzi razvoj kontejnerskih brodova prije pedeset godina.

Danas svjetsku kontejnerizaciju označavaju veliki i brzi kontejnerski brodovi, kontejnerski terminali u lukama, velike specijalne dizalice koje su izmjenile izgled velikih morskih luka u svijetu. 


\subsection{Kontejnerski terminali}

Pomorski terminali kao mjesto povezivanja pomorskog i kopnenog prijevoza imaju veliko značenje u razvoju sustava kontejnerizacije te mogu predstavljati ograničavajući faktor funkcioniranja suvremenih tehnologija prometa.

U novije vrijeme posebice se razvijaju kontejnerski terminali u velikim pomorskim lukama svijeta koji ne mogu izdržati konkurenciju bez stalnoga razvoja novih oblika i strukture terminala te posebice bez potrebne opreme. Povezivanje terminala s okruženjem, automatizacija i informatika predstavljaju uvijet uspješnog funkcioniranja najvećih lučkih i kontejnerskih terminala. Zbog toga kontejnerski terminali zahtjevaju neprestano istraživanje i usvršavanje.

Zbog unaprijeđenja tradicionalnih dokumentarnih procedura koje postaju zapreka ubrzanog i efikasnog poslovanja te komuniciranja razvija se suvremeni informacijski sustav koji osigurava komuniciranje između računarskih sustava na različitim mjestima na kopnu i brodovima. Upravo zahtjeve logistike potpuno zadovoljavaju kontejnerski terminali, posebice oni pomorski, locirani u lukama.

Lučki kontejnerski terminal dio je lučkog sustava koji predstavlja posebno izgrađen i opremljen objekt namjenjen prekrcaju kontejnera izravnim ili posrednim rukovanjem između morskih brodova i kopnenih prijevoznih sredstava. Kontejnerski terminal povezuje najmanje dva prometna sustava, a za uspješno odvijanje procesa upotrebljavaju se specijalizirana prekrcajna sredstva.

Razvitkom pomorskih kontejnerskih i multimodalnih centara na kopnu omogućuje se stvaranje cjelovite mreže terminala koja je ugrađena u jedinstveni prometni sustav koncipiran na logističkim načelima. Tako koncipirani prometni tokovi na jednom mjestu predstavljaju najvažnije infrastrukturne objekte ukupne logistike, čiji nedostatak u novije vrijeme stvara velike probleme u funkcioniranju gospodarstva mnogih zemalja, a posebice onih koje imaju značajan geoprometni položaj.

\section{5 Željeznički i cestovni promet u funkciji kontejnerizacije}

Imajući na umu složeni sustav kontejnerizacije i njegove glavne elemente, može se zaključiti da elementi željezničkog i cestovnog prometa imaju značaj početnih i završnih elemenata kontejnerizacije bez kojih nema cjelovitog sustava kontejnerizacije. Polazeći od standardizacije pojedinih oblika kontejnerizacije i potrebe povezivanja svih elemenata, željeznički i cestovni promet zaslužuju posebnu pozornost i stalno istraživanje.

Analizom željezničkog i cestovnog prometa treba naglasiti razvoj kontejnerskih kopnenih terminala te sustav kontejnerskih vlakova i kamionskih vlakova. Budući da se većina kopnenih kontejnerskih terminala nalazi u čvorištima željezničkih i cestovnih prometnica sa jakim gravitacijskim zaleđem, oni se danas najčešće izgrađuju kao željezničko-cestovni kontejnerski terminali.

U sustavu željezničkog i cestovnog prometa, željezničko-cestovni suvremeni terminali trebaju zadovoljiti postojeće potrebe te osigurati daljnji fazni razvoj kontejnerizacije. Osim terminala, 
najvažnije specifične značajke željezničkog transporta i prometa su željeznička infrastruktura i željeznička suprastruktura.

Analizirajući osnovne značajke glavnih elemenata kontejnerizacije, treba naglasiti da nema uspješne kontejnerizacije bez standardizacije, unifikacije i povezivanja svih glavnih elemenata kontejnerizacije.

Upravo sve navedeno govori u prilog visokoj razini kontejnerizacije u razvijenim zemljama svijeta te pokazuje manje razvijenim zemljama kako trebaju razvijati i afirmirati glavne elemente kontejnerizacije.

Osim glavnih elemenata kontejnerizacije, treba naglasiti i ostale logističke djelatnosti u vezi s transportom i prometom kao što su djelatnosti međunarodnog špeditera, djelatnosti morskih luka, djelatnosti lučkih slagača, djelatnosti skladišta i terminala, djelatnosti carinskih skladišta, djelatnosti slobodnih zona, djelatnosti robnotransportnih centara, djelatnosti robnodistribucijskih centara, djelatnosti robnotrgovinskih centara, djelatnosti logističkih centara, djelatnosti pomorskih agenata, djelatnosti izvršitelja ugovorne kontrole, djelatnosti osiguravajućih društava, djelatnosti tijela državne uprave, ostale logističke djelatnosti.

\section{STANJE KONTEJNERSKOG PROMETA U SVIJETU}

Svjetska pomorska trgovina izražena u prevezenim kontejnerima vrlo je značajan pokazatelj stanja kontejnerskog prometa u svijetu. Analizirajući promet kontejnera tijekom godina može se zaključiti stalni rast prevezenoga tereta u kontejnerima. Zbog toga znanstvenici i stručnjaci postavljaju pitanje što je to u kontejnerima da osiguravaju tako značajno širenje i afirmaciju. Kontejnerski promet je specifičan u odnosu na prijevoz roba na konvencionalne načine $u$ tome što ima na raspolaganju različite standardizirane kontejnere od 20, 40, 45, 48 i 56 stopa, u koje se mogu ukrcavati, transportirati i iskrcavati tereti.

Osim toga u novije vrijeme specijalne robe se prevoze u posebnim ili specijalnim standardnim kontejnerima koji osiguravaju siguran i brz prijevoz roba od vrata do vrata.

Sve navedeno, uz prije navedene važnosti i prednosti kontejnerizacije osigurava prijevoz velikih količina roba u međunarodnoj pomorskoj trgovini i razmjeni.

Količine prevezenih roba u kontejnerima u međunarodnoj robnoj razmjeni u zadnjih nekoliko desetljeća navode se u tablici 1. 
Tablica 1. Svjetska pomorska trgovina prevezenog tereta u kontejnerima 1980-2017. godine

\begin{tabular}{|c|c|}
\hline Godina & Promet tereta u kontejnerima / Milijuni tona \\
\hline 1980. & 102 \\
\hline 1985. & 152 \\
\hline 1990. & 234 \\
\hline 1995. & 371 \\
\hline 2000. & 598 \\
\hline 2005. & 1001 \\
\hline 2010. & 1291 \\
\hline 2015. & 1660 \\
\hline 2016. & 1734 \\
\hline 2017. & 1834 \\
\hline
\end{tabular}

Izvor: www.statista.com (30. 11. 2019.), obrada autora

Iz tablice 1 vidljiv je prijevoz i porast prevezenih roba u razdoblju 1980. do 2017. godine.

Evidentan porast prevezenih količina tereta posljedica je neprekidnog ulaganja u kontejnerski promet i njegove glavne elemente. Sukladno razvoju svjetske pomorske trgovine i kontejnerizacije potrebno je posvetiti posebnu pažnju prometu kontejnera u najvećim svjetskim kontejnerskim lukama.

Zbog uvida u preglednost najvećih svjetskih kontejnerskih luka i terminala u tablici 2. daje se pregled najvećih kontejnerskih luka prema broju prekrcanih kontejnera od 2014. do 2018. godine. 
B. Rudić, E. Gržin: Razvoj kontejnerizacije u svijetu i analiza kontejnerskog prometa u luci Rijeka Zbornik Veleučilišta u Rijeci, Vol. 8 (2020), No. 1, pp. 427-442

Tablica 2. Promet kontejnera u 20 najvećih svjetskih kontejnerskih luka prema TEU-a od 2014. do 2018. godine

\begin{tabular}{|c|c|c|c|c|c|c|}
\hline Rang & Luka & $\begin{array}{l}\text { Količina } 2018 . \\
\text { (milijun TEU) }\end{array}$ & $\begin{array}{l}\text { Količina } 2017 . \\
\text { (u mil. TEU) }\end{array}$ & $\begin{array}{l}\text { Količina 2016.(u } \\
\text { mil. TEU) }\end{array}$ & $\begin{array}{l}\text { Količina } 2015 . \\
\text { (u mil. TEU) }\end{array}$ & $\begin{array}{l}\text { Količina } \\
\text { 2014.(u mil. } \\
\text { TEU) }\end{array}$ \\
\hline 1 & Šangaj, Kina & 42.01 & 40.23 & 37.13 & 36.54 & 35.29 \\
\hline 2 & Singapur & 36.60 & 33.67 & 30.90 & 30.92 & 33.87 \\
\hline 3 & Shenzhen, Kina & 27.74 & 25.21 & 23.97 & 24.20 & 24.03 \\
\hline 4 & $\begin{array}{l}\text { Ningbo- } \\
\text { Zhoushan, Kina }\end{array}$ & 26.35 & 24.61 & 21.60 & 20.63 & 19.45 \\
\hline 5 & Luka Guangzhou & 21.87 & 20.37 & 18.85 & 17.22 & 16.16 \\
\hline 6 & $\begin{array}{c}\text { Busan, Južna } \\
\text { Koreja }\end{array}$ & 21.66 & 20.49 & 19.85 & 19.45 & 18.65 \\
\hline 7 & $\begin{array}{l}\text { Hong Kong, SAR, } \\
\text { Kina }\end{array}$ & 19.60 & 20.76 & 19.81 & 20.07 & 22.23 \\
\hline 8 & Qingdao & 18.26 & 18.30 & 18.01 & 17.47 & 16.62 \\
\hline 9 & Tianjin, Kina & 16.00 & 15.07 & 14.49 & 14.11 & 14.05 \\
\hline 10 & $\begin{array}{l}\text { Jebel Ali, Dubai, } \\
\text { Ujedinjeni } \\
\text { Arapski Emirati }\end{array}$ & 14.95 & 15.37 & 15.73 & 15.60 & 15.25 \\
\hline 11 & $\begin{array}{l}\text { Rotterdam, } \\
\text { Nizozemska }\end{array}$ & 14.51 & 13.73 & 12.38 & 12.23 & 12.30 \\
\hline 12 & $\begin{array}{l}\text { Port Klang, } \\
\text { Malezija }\end{array}$ & 12.32 & 13.73 & 13.20 & 11.89 & 10.95 \\
\hline 13 & $\begin{array}{c}\text { Antwerpen, } \\
\text { Belgija }\end{array}$ & 11.10 & 10.45 & 10.04 & 9.65 & 8.98 \\
\hline 14 & $\begin{array}{l}\text { Kaohsiung, } \\
\text { Tajvan, Kina }\end{array}$ & 10.45 & 10.27 & 10.46 & 10.26 & 10.59 \\
\hline 15 & Xiamen, Kina & 10.00 & 10.38 & 9.61 & 9.18 & 10.13 \\
\hline 16 & Dalian, Kina & 9.77 & 9.70 & 9.61 & 9.45 & 10.13 \\
\hline 17 & Los Angeles, SAD & 9.46 & 9.43 & 8.86 & 8.16 & 8.33 \\
\hline 18 & $\begin{array}{c}\text { Tanjung Pelepas, } \\
\text { Kina }\end{array}$ & 8.96 & 8.38 & 8.28 & 9.10 & 8.50 \\
\hline 19 & $\begin{array}{l}\text { Hamburg, } \\
\text { Germany }\end{array}$ & 8.73 & 8.86 & 8.91 & 8.82 & 9.73 \\
\hline 20 & $\begin{array}{l}\text { Long Beach, } \\
\text { U.S.A. }\end{array}$ & 8.09 & 7.54 & 6.80 & 7.19 & 6.82 \\
\hline
\end{tabular}

Izvor: www.worldshipping.org

Podaci u tablici 2 pokazuju da se najviše svjetskog kontejnerskog prometa odvija u azijskim zemljama, pri čemu se posebno ističe dominacija kineskih luka. Od 20 svjetskih kontejnerskih luka, 
pola ih se nalazi u Kini. Najveće europske luke Rotterdam, Antwerpen i Hamburg zauzimaju u 2018. godini 11., 13. i 19. mjesto u poretku najvećih svjetskih kontejnerskih luka.

Nadalje, iz tablice 2 vidljivo je da luka Šangaj (Kina), kao vodeća luka u prometu kontejnera, ima udio od 12 \% ukupnog prometa u promatranim lukama. Ujedno je promet kontejnera u toj luci u 2018. godini veći za $19 \%$ u usporedbi s prometom u 2014. godini. Udio najveće europske luke, Rotterdam (Nizozemska), iznosi $4 \%$ ukupnog prometa u promatranim lukama, te je u 2018. godini zabilježen porast prometa za $18 \%$ u odnosu na 2014 . godinu.

Osim toga, iz podataka u tablici 2 vidljivo je da su neke luke u promatranom razdoblju zabilježile smanjenje prometa u odnosu na prethodnu godinu. Tako je, na primjer, luka Singapur imala pad prometa u 2015. i 2016. godini za $9 \%$ tj. za 0,6 \% u odnosu na prethodnu godinu. $U$ istom razdoblju je smanjen promet kontejnera i u luci Hong Kong i to u 2015. godini za oko $10 \%$, a u 2016. godini za oko $1 \%$ u usporedbi s prometom kontejnera u godini ranije. U luci Jebel Ali Dubai promet je smanjen za oko $2 \%$ u 2017. godini, a u 2018. godini za oko $3 \%$ u odnosu na prethodnu godinu.

Također, u 2018. godini, uz ranije spomenute luke Hong Kong i Jebel Ali Dubai, pad prometa u odnosu na 2017. godinu zabilježen je i u lukama Port Klang (Malezija) (10\%), Xiamen (Kina) (4\%), Hamburg (Njemačka) (1,5\%) i Qingdao (Kina) (0,2 \%).

Prateći ukupne kapacitete kontejnerski brodova u pomorskoj trgovini zadnjih desetljeća, navodi se grafikon 1.

Grafikon 1. Kapaciteti kontejnerskih brodova u pomorskoj trgovini od 1980. do 2019. godine (u milijunima DWT-a)

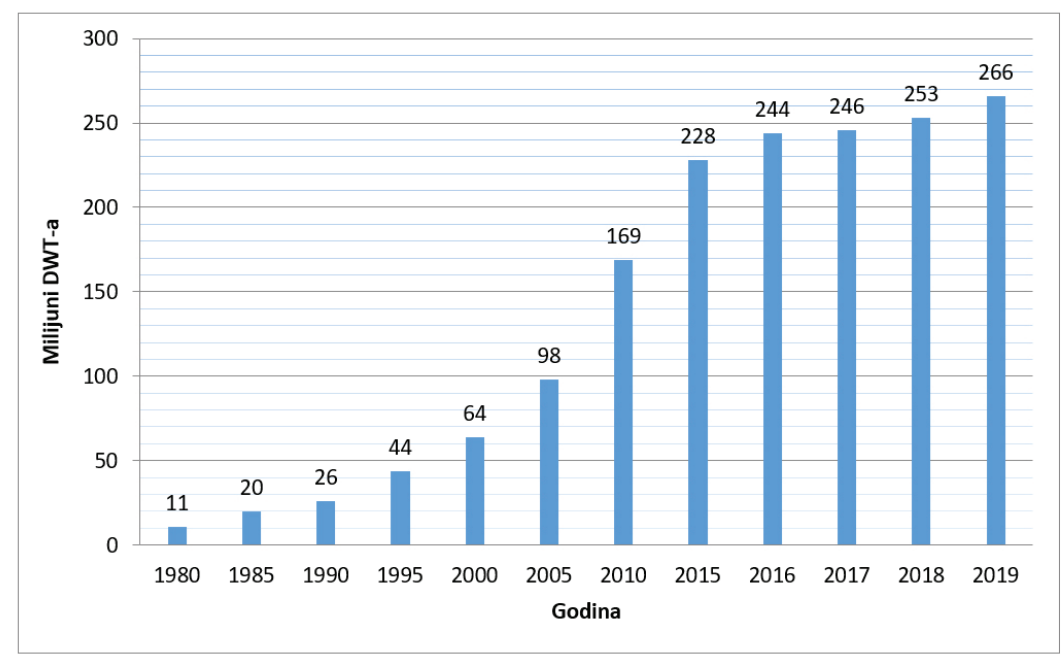

Izvor: : www.statista.com (30.11. 2019.)

Iz grafikona 1 može se vidjeti stalan rast ukupnih kapaciteta kontejnerskih brodova u pomorskoj trgovini od 1980. do 2019. godine. U razdoblju od prvih promatranih 20 godina (od 1980. do 2000. godine) vidljiv je porast od $481 \%$, tj. kapaciteti kontejnerskih brodova su u navedenom razdoblju 


\section{B. Rudić, E. Gržin: Razvoj kontejnerizacije u svijetu i analiza kontejnerskog prometa u luci Rijeka}

Zbornik Veleučilišta u Rijeci, Vol. 8 (2020), No. 1, pp. 427-442

porasli 4,8 puta. Veliko petogodišnje povećanje vidljivo je u razdoblju od 2005. do 2010. godine i to za 72 \%. Nakon 2015. godine rast kapaciteta kontejnerskih brodova se usporio, te je u 2019. godini zabilježen porast kapaciteta od $17 \%$ u odnosu na 2015. godinu. Promatrajući razdoblje od 2015. godine do danas, kapaciteti kontejnerskih brodova su se u prosjeku povećavali za 8,5 milijuna DWT-a godišnje.

Naglo širenje kontejnerizacije u pomorskom prometu, podrazumijeva veliki porast broja kontejnerskih brodova raznih kapaciteta. Stanje broja kontejnerskih brodova velikih svjetskih kontejnerskih brodara vidljivo je iz grafikona 2.

Grafikon 2. Vodeći kontejnerski brodari prema broju brodova na dan 30. studeni 2019. godine

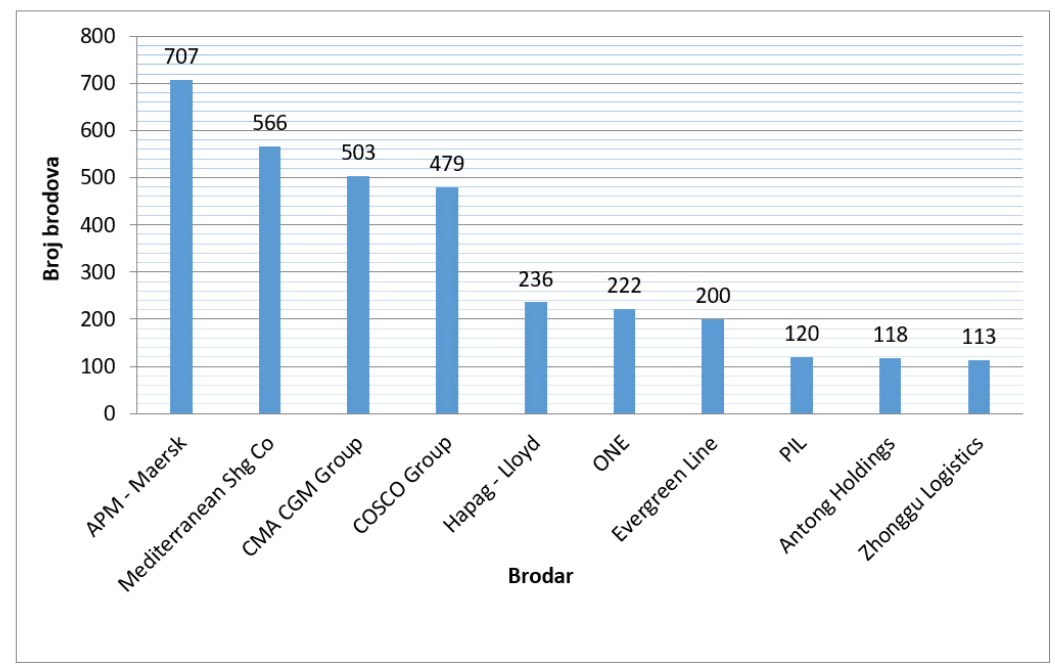

Izvor: www.statista.com (30.11. 2019.)

Prema podacima iz grafikona 2 vidljivo je da je APM-Maersk vodeći kontejnerski brodar s ukupno 707 brodova, što čini udio od oko $22 \%$ u ukupnom broju brodova promatranih kontejnerskih brodara. Više od 500 brodova imaju još dva brodara, Mediterranean Shg Co i CMA CGM Group, svaki s udjelom od $17 \%$ tj. $15 \%$ u ukupnom broju brodova promatranih kontejnerskih brodara. Većina promatranih brodara ima manje od 500 brodova u svojoj floti.

Osim broja kontejnerskih brodova u svijetu, posebnu pozornost privlače i ukupni kapaciteti kontejnerskih brodara u TEU. Kapaciteti najznačajnijih kontejnerskih brodara prikazuju se na grafikonu 3. 
Grafikon 3. Vodeći svjetski kontejnerski brodari na dan 30. studeni 2019. prema kapacitetu TEU-a

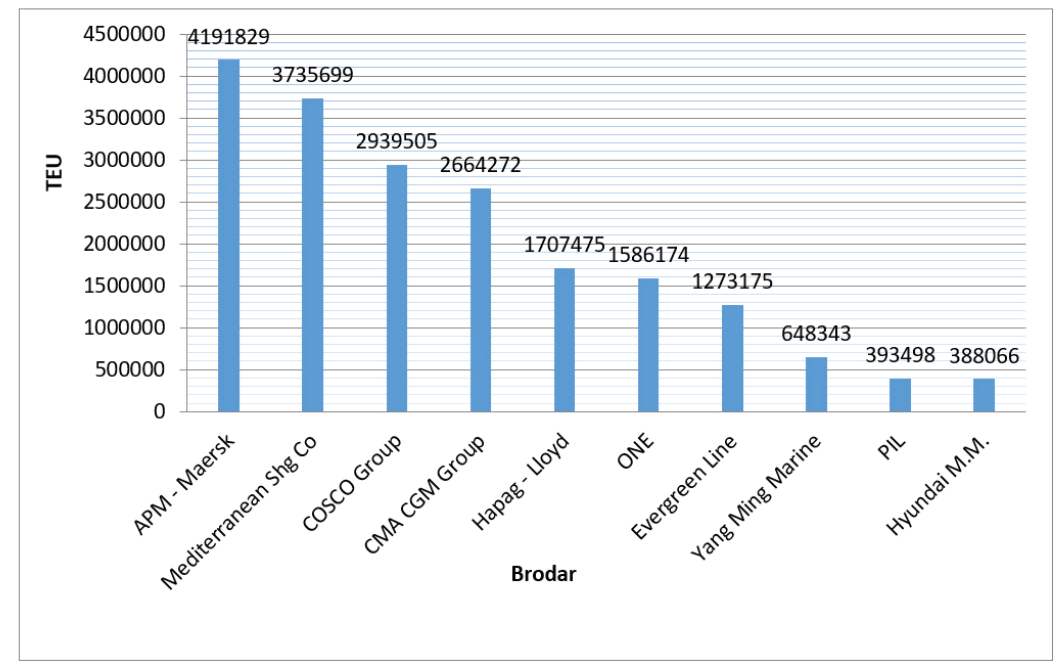

Izvor: www.statista.com (30.11. 2019.)

Podaci na grafikonu 3 pokazuju da je vodeći kontejnerski brodar APM Maersk, s ukupnim kapacitetom 4,2 mil. TEU-a. Većina najvećih brodara ima kapacitet veći od 1 mil. TEU-a.

\section{ANALIZA KONTEJNERSKOG PROMETA U LUCI RIJEKA}

U literaturi postoji niz istraživanja o kontejnerskim lukama, njihovom prometu, uslugama i pokazateljima poslovanja. Prema Hsu (2013), to je posljedica sve veće važnosti kontejnerskog prometa na globalnoj razini.

$\mathrm{Ng}$ (2006) je istraživao atraktivnost glavnih pretovarnih luka u Sjevernoj Europi, te zaključio da su najatraktivnije sjevernoeuropske luke Hamburg i Roterdam, a iza njih se nalaze Antwerpen i Bremerhaven. Notteboom (2010) u svom radu detaljno analizira promet kontejnera u europskim lukama. Urbanyi-Popiolek i Klopott (2016) istraživali su utjecaj kontejnerskih luka na lučke gradove u Poljskoj. Rezultati istraživanja su pokazali da povećanje kontejnerskog prometa $u$ lukama ima pozitivne i negativne posljedice na urbana područja u blizini luka. Hlali i Hammami (2019) analiziraju kontejnerski promet u lukama u Alžiru, Tunisu i Maroku i zaključuju da je lučka infrastruktura osnovni nedostatak promatranih luka. Olapujo (2019) je analizirao tržišni udio kontejnerskog prometa u nigerijskim lukama. Rezultati su pokazali da luke u zapadnom dijelu države ostvaruju veći promet u odnosu na luke u istočnom dijelu države.

Zbog značenja kontejnerizacije za prometni pravac od Rijeke prema Zagrebu i Budimpešti te dostignute razine funkcioniranja kontejnerskog terminala u riječkoj luci, vrlo važno je analizirati razvoj kontejnerizacije u Rijeci i posebice kontejnerskog terminala u Rijeci.

Pod utjecajem ratnih rizika i tehnološke stagnacije kontejnerskog terminala u Rijeci te neadekvatne povezanosti riječke luke sa zaleđem, u razdoblju od 1990. do 1999. zabilježen je stalan pad prometa 
kontejnera u riječkoj luci. Tako je na kontejnerskom terminalu Brajdica u Rijeci 1999. godine ostvaren promet od samo 10.134 TEU-a.

Nakon 1999. godine započinje tehnološka i organizacijska modernizacija kontejnerskog terminala, a rezultat je toga porast prometa kontejnera već 2004. godine na 60.000 TEU-a, što je najbolje pokazalo značenje kontejnerkog terminala u sustavu kontejnerizacije i afirmacije luke Rijeka kao najznačajnije logističke i prometne točke ukupnog prometnog sustava Republike Hrvatske.

U povećanju prometa kontejnera u Rijeci bitno su sudjelovali u početku feeder servisi domaćih i stranih kontejnerskih brodara te su osim feeder servisa 2003. godine započeli riječku luku ticati veliki kontejnerski brodovi (matice) poznatih svjetskih kontejnerskih brodara koji i danas tiču kontejnersku luku.

Nakon uspješnog širenja kontejnerizacije na kontejnerskom terminalu Brajdica u Rijeci, Lučka uprava Rijeka prišla je izgradnji druge faze kontejnerskog terminala Brajdica koja je završena 2013. godine. Glavni operater na kontejnerskom terminalu Brajdica je koncesionar Jadranska vrata d.d. Druga faza izgradnje kontejnerskog terminala Brajdica uključivala je četiri komponenete Rudić et al. (2013) uključivala je:

- produženje obale 330 metara te pratećeg skladišnog prostora; izgradnja nove obale, te $50.0000 \mathrm{~m}^{2}$ površine. Završetkom izgradnje ove druge faze udvostučiti će se kapacitet skladištenja kontejnera. Nabavom dodatne prekrcajne opreme omogućio bi se istovremeni prekrcaj dvaju kontejnerskih brodova na jednoj obali.

- izgradnja novog ulazno-izlaznog punkta

- željeznička ukrcajno-iskrcajna stanica

- objekti servisnih djelatnosti

Imajući na umu strategiju širenja kontejnerizacije u svijetu Lučka upava Rijeka, razmišlja o novom kontejnerskom terminalu Zagrebačka obala u Rijeci. Tako najvažniji i najveći kapitalni projekt u sklopu Rijeka Gateway projekta je upravo izgradnja novog kontejnerskog terminala na Zagrebačkom pristaništu koji se streba realizirati kroz dvije osnovne faze. Prva faza projekta uključuje izgradnju obale dužine 400 metara i završena je 2019. godine. Lučka uprava Rijeka nastavlja javni natječaj za koncesionara koji bi bio operator na terminalu te je zamišljeno da isti nabavi i stavi u funkciju opremu terminala te je zamišljeno da se u drugoj fazi izgradnje produži terminal za 280 metara obalnog zida sa zaobaljem kako bi terminal u konačnici iznosio 680 metara dužine. Realiziranjem tog plana na Zagrebačkoj obali ukupni kapaciteti godišnji kontejnerskog terminala Zagrebačka obala iznosili bi 500.000 TEU-a. Uz navedeni terminal bitna je izgradnja ceste D403 koja bi osigurala uspješno funkcioniranje kontejnerskog terminala te doprinijela novoj kvaliteti odvijanja prometa u zapadnom dijelu grada.

U nastavku ovog dijela rada prikazat će se rezultati analize kontejnerskog prometa luke Rijeka, s obzirom na to da luka Rijeka u Hrvatskoj ima vodeću ulogu u kontejnerskom prometu. Analiza obuhvaća promet kontejnera u razdoblju od 2008. do 2018. godine. 
Tablica 3. Kontejnerski promet luke Rijeka od 2008. do 2018. godine

\begin{tabular}{|c|c|c|c|c|c|}
\hline Godine & $\begin{array}{c}\text { Kontejnerski } \\
\text { promet } \\
\text { (u TEU) }\end{array}$ & $\begin{array}{c}\text { Verižni } \\
\text { indeks }\end{array}$ & $\begin{array}{c}\text { Stopa } \\
\text { promjene (\%) }\end{array}$ & $\begin{array}{c}\text { Bazni } \\
\text { indeks }\end{array}$ & $\begin{array}{c}\text { Stopa } \\
\text { promjene (\%) }\end{array}$ \\
\hline 2008. & 168761 & - & - & 100,00 & 0,00 \\
\hline 2009. & 130740 & 77,47 & $-22,53$ & 77,47 & $-22,53$ \\
\hline 2010. & 137048 & 104,82 & 4,82 & 81,21 & $-18,79$ \\
\hline 2011. & 150677 & 109,94 & 9,94 & 89,28 & $-10,72$ \\
\hline 2012. & 171945 & 114,11 & 14,11 & 101,89 & 1,89 \\
\hline 2013. & 169943 & 98,84 & $-1,16$ & 100,70 & 0,70 \\
\hline 2014. & 192004 & 112,98 & 12,98 & 113,77 & 13,77 \\
\hline 2015. & 200102 & 104,22 & 4,22 & 118,57 & 18,57 \\
\hline 2016. & 214348 & 107,12 & 7,12 & 127,01 & 27,01 \\
\hline 2017. & 249975 & 116,62 & 16,62 & 148,12 & 48,12 \\
\hline 2018. & 260375 & 104,16 & 4,16 & 154,29 & 54,29 \\
\hline
\end{tabular}

Izvor: https://www.portauthority.hr/statistike-i-tarife/ (30.11. 2019.), obrada autora

Iz tablice 3 vidljivo je da kontejnerski promet u luci Rijeka u promatranom razdoblju raste u svim godinama u odnosu na prethodnu, osim u 2009. i 2013. godini. $U$ 2009. godini promet je bio u padu za 22,53 \% u odnosu na 2008. godinu, što je posljedica ekonomske krize. Blagi pad prometa zabilježen je u 2013. godini i to za 1,16 \% u odnosu na prethodnu godinu. Najveći porast kontejnerskog prometa u luci Rijeka u odnosu na prethodnu godinu bio je 2017. godine, kada je promet kontejnera porastao za $16,62 \%$ u usporedbi s godinom ranije. Sličan porast prometa bio je i 2012. godine, za 14,11 \% u odnosu na 2011. godinu. U 2018. godini kontejnerski promet raste za $4,16 \%$, što je najmanje povećanje prometa u odnosu na prethodnu godinu u promatranom razdoblju.

Osim toga, rezultati u tablici 3 pokazuju da je u odnosu na 2008. godinu, kontejnerski promet bio u padu do 2011. godine, kada je promet bio za 10,72 \% manji nego u 2008. godini. Od 2012. godine kontejnerski promet bilježi pozitivne rezultate u odnosu na 2008. godinu, te se u posljednjoj promatranoj godini ostvaruje rast od 54,29 \% u usporedbi s kontejnerskim prometom u 2008 . godini.

Ujedno, analizirajući tendenciju kretanja kontejnerskog prometa, dolazi se do zaključka da je promet kontejnera u luci Rijeka u promatranih 10 godina rastao u prosjeku za 11.689,26 TEU-a godišnje. 


\section{B. Rudić, E. Gržin: Razvoj kontejnerizacije u svijetu i analiza kontejnerskog prometa u luci Rijeka}

Zbornik Veleučilišta u Rijeci, Vol. 8 (2020), No. 1, pp. $427-442$

\section{ZAKLJUČAK}

Osnovni cilj ovog rada bio je ukazati na važnost kontejnerizacije, prikazati stanje kontejnerskog prometa u svijetu i analizirati kontejnerski promet u Hrvatskoj na primjeru luke Rijeka, kao najprometnije hrvatske kontejnerske luke.

Analizirajući sve navedeno u ovome radu, može se zaključiti kako postoji velika važnost kontejnerizacije jer kontejnerizacija kao suvremena tehnologija prometa podrazumijeva realizaciju suvremenih ekonomskih i logističkih strategija kao što su: brzina, sigurnost i racionalnost prijevoza u dostavi robe od vrata dovrata.

Stanje kontejnerskog prometa u svijetu pokazuje stalan rast. Tako je 1980. godine promet robe $\mathrm{u}$ kontejnerima $\mathrm{u}$ pomorskoj trgovini iznosio 102 milijuna tona da bi 2017. prijevoz robe $u$ kontejnerima narastao na 1.834 .000 tona.

Istraživanjem i analizom u ovome radu analizirano je 20 najvećih svjetskih kontejnerskih luka, među kojima je luka Šangaj koja je imala u 2018. godini promet od 42 milijuna TEU.

Rezultati pokazuju konstantni rast svih elemenata kontejnerizacije na svjetskoj razini. Na razini Hrvatske, na primjeru luke Rijeka, također su vidljivi pozitivni rezultati na području kontejnerskog prometa, iako su oni daleko ispod rezultata vodećih europskih kontejnerskih luka.

S obzirom na to da će dostupnost luke u smislu njenog geografskog položaja i povezanosti sa zaleđem u vidu razvijene željezničke i cestovne infrastrukture imati i dalje bitnu ulogu u privlačenju brodara i rastu prometa, u budućim bi se istraživanjima o kontejnerskom prometu trebao analizirati i utjecaj tog elementa sustava kontejnerizacije na poslovanje kontejnerskih luka. Nadalje, buduća istraživanja mogu biti usmjerena i na detaljniju analizu kontejnerskog prometa i poslovanja u svim kontejnerskim lukama u Hrvatskoj. Kako bi se utvrdila relativna važnost i uloga hrvatskih luka u okruženju, predlaže se provesti komparativna istraživanja svih elemenata kontejnerizacije u konkurentskim kontejnerskim lukama u susjednim državama.

\section{LITERATURA}

Bernhofen, D., El-Sahli, Z., Kneller R. (2016) “Estimating the Effects of the Container Revolution on World Trade”, Journal of International Economics, pp. 36-50. DOI: http://dx.doi.org/10.7708/ijtte.2019.9(2).05

Erak, I., Ivče, R., Komadina, P. (2015) "Suvremeni kontejnerski brodovi i fenomen parametrijskog ljuljanja", Pomorski zbornik, 49-50(1), pp. 75-86.

Heaver, T. (2002) "The evolving roles of shipping lines in international logistics", International journal of maritime economics, 4, pp. 210-230.

Hlali, A., Hammami, S. (2019) "The evolution of containerization and its impact on the Maghreb ports", Annals of Marine Science, 3(1), pp. 1-5. DOI: http://dx.doi.org/10.17352/ams.000012

Hsu, W. K. K. (2013) “Improving the service operations of container terminals", The International Journal of Logistics Management, 24(1), pp. 101-116.

Mišković, D., Ivče, R., Popović, M. (2016) “Tehnološki razvoj kontejnerskog broda kroz povijest”, Naše more, 63(1 Supplement), pp. 9-15. https://doi.org/10.17818/NM/2016/1.8 
$\mathrm{Ng}, \mathrm{K}$. Y. (2006) "Assessing the attractiveness of ports in the North European container transhipment market: an agenda for future research in port competition", Maritime Economics \& Logistics, 8(3), pp. 234-250.

Notteboom, T. (2010) "Concentration and the formation of multi-port gateway regions in the European container port system: an update" Journal of transport geography, 18(4), pp. 567-583.

Olapoju O. M. (2019) “An Appraisal of Containerization in Ports of Western and Eastern Nigeria”, International Journal for Traffic and Transport Engineering, 9(2), pp. 188 - 197.

Rudić, D., Hlača, B., Gržin, E. (2013) "Strateške odrednice kontejnerskog prometa u riječkoj luci", Zbornik Veleučilišta u Rijeci, 1(1), pp. 259-277.

Urbanyi-Popiolek, I., Klopott, M. (2016) "Container terminals and port city interface - a study of Gdynia and Gdańsk ports", Transportation Research Procedia, 16, pp. 517 - 526

Vladimir, N., Malenica, Š., Senjanović, I., De Lauzon, J., Im, H., Cho, D. (2017) “Evaluation of structural design of ultra large container vessel" Rad Hrvatske akademije znanosti i umjetnosti. Tehničke znanosti, (531=18), pp. 27-46.

www.portauthority.hr/rgp-kontejnerski-terminal-jadranska vrata (2019)

www.statista.com/statistics/198214/total-teus-of-worldwide-leading-container-ship-operators-in-2011/ (2019)

www.statista.com/statistics/263291/container-shipping-companies-worldwide-number-of-ships/ (2019)

www.statista.com/statistics/267603/capacity-of-container-ships-in-the-global-seaborne-trade/ (2019)

www.worldshipping.org/about-the-industry/global-trade/top-50-world-container-ports (2019)

Zelenika, R., Mrvčić, A., Pavlić Skender, H. (2011) “Analiza I ocjena stupnja uspješnosti u poslovanju teretnih morskih luka u Republici Hrvatskoj”, Naše more, 58(1-2), pp. 9-21. 


\title{
THE DEVELOPMENT OF CONTAINERIZATION IN THE WORLD AND THE ANALYSIS OF CONTAINER TRAFFIC IN THE PORT OF RIJEKA
}

\author{
Barbara Rudić \\ M Econ, Senior Lecturer, Polytechnic of Rijeka, Vukovarska 58, 51000 Rijeka, Croatia; \\ e-mail: barbara.rudic@veleri.hr

\section{Erika Gržin} \\ Spec. Ing. Traff., Lecturer, Polytechnic of Rijeka, Vukovarska 58, 51000 Rijeka, Croatia; \\ e-mail: erika.grzin@veleri.hr
}

\begin{abstract}
Containerization has influenced the development of international trade and has become an irreplaceable transport mode combining maritime, road and rail transport in a complete transport chain. The purpose of this paper is to show the importance of containerization, to give an overview of the situation of the container traffic in the world and to analyse the container traffic in Croatia, taking Rijeka as an example. The paper focuses on the development of containerization, as well as on indicators connected with the container traffic in the world's busiest seaports together with the indicators from the largest container ship operators. The paper stresses the importance of the main elements of containerization and other participants in the system of containerization. The collected data has been analysed using descriptive statistics. The results obtained show continuous growth of all the elements of containerization on the global level. In Croatia, using Rijeka as an example, positive results are also visible in the field of container transport.
\end{abstract}

Key words: development of containerization, container traffic, container ship, port of Rijeka, analysis 